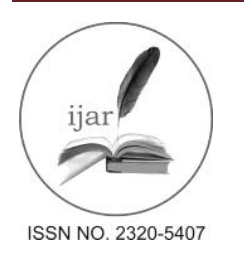

Journal homepage: http://www.journalijar.com

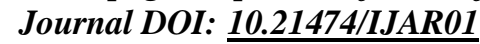

INTERNATIONAL JOURNAL

OF ADVANCED RESEARCH

RESEARCH ARTICLE

\title{
IMPACT OF INTERNAL MARKETING ON MARKETING PERFORMANCE MANAGEMENT: AN INVESTIGATIONOF JORDANIAN BANKING SECTOR.
}

\author{
Dr. Mohemmd Shura, Dr. Ayyoub Alsawalhah.
}

\section{Manuscript Info}

Manuscript History:

Received: 19 March 2016

Final Accepted: 26 April 2016

Published Online: May 2016

Key words:

*Corresponding Author

Mohemmd shura.

\begin{abstract}
This study aimed to identify the impact of internal marketing on marketing performance management in the Jordanian banks. The importance of this study came from a scientific and academic analysis of the correlation between internal marketing and marketing performance management in the Jordanian banks, the importance of this study is to apply the results in the Jordanian banking industry for the first time. The population study consisted of all the banks listed on Amman Stock Exchange, the (SPSS) program is used to analyze the sample which consists of (193) individuals, the study results: that the internal marketing affects the marketing performance management in the Jordanian banks. The study recommendations :there is need to spread the culture of internal marketing to support the senior marketing management at the Jordanian banks, in order to evaluate the performance of marketing.
\end{abstract}

Copy Right, IJAR, 2016.. All rights reserved.

\section{Introduction;-}

The marketing characterized by the result-producing function of the organization and the marketing having the responsibility of achieving profitable revenue growth by means of demand creation. The marketing performance measurements not only influences the overall organizational performance, but also affects the marketing functions within the organization (Mills,2010). One of the most important marketing aspect is the internal marketing that have a positive direct effect on the organizational performance (Abzari et al 2011). An important concern in marketing theory is the relationship between marketing strategy and stakeholders value, the most articulation concerns in any organization (Raji Srinivasan and Sundar Bharadwaj,2004; Srivastava et al 1988). One of the articulated elements that affect the overall marketing performance is the employees that worke directly with the product or services that the organization produces. The banking industry have some specifications that come from the direct influence of the employees that work directly with the customers, the employees play a significant role in the marketing and delivering the banks products, which exaggerated responsibility of the marketing role of the employees, the internal marketing comes to enhance the employees to do their best in the overall responsibilities that they have.

\section{Literature Review:- Internal Marketing:-}

The internal marketing has a positive direct effect on banks' market orientation (Abzari et al ,2011), Awwad \& Agti (2011) mentioned that the importance of the internal marketing in supporting the competitive advantage of any organization, Berry (1980) was coined the term of internal marketing as the promotion of the firm to its employees, the internal marketing was defined by many authors, Woodruffe (1995) defined it as "Treating both employees and customers with equal importance through proactive programs in order to achieve the objectives of the organization", many scholars as Gronroos (1981); Joseph (1996); Anselmo (2008) defined the internal marketing as the "Satisfying the employee's needs". All authors agreed on the role of internal marketing to enhancing the performance of the entire organization. Berry and Parasuraman (1991) defined the internal marketing as:"Attracting, developing, 
motivating satisfy their needs...The philosophy of treating employees as customers..... And the strategy of shaping jobs to fit human needs." This definition explained that the employees are an internal customer that the organization must satisfy their needs and the employees are the internal generator that gives the organization its marketing leverage power. Shiu and Yu (2010) addressed the importance of the internal marketing in the service organizations in which the staff play major function to attract customers and preserve contact with them. The banks that try to achieve a long-term prospects must look to the internal marketing as a fundamental issue when they deal with their customers. Abzari (2009)explains the relationship between the organization and their customer from the internal marketing, the dependency relationship connect between the organization marketing performance and the internal marketing. The internal marketing transposes the organization to be equipped by the ability to compete in the market by the managed performance. Hogg et al (1998) explained the main dimensions for the internal marketing: communication, staff training; appraisal and feedback; and customer consciousness. Tsai and Tang ( 2008) mentioned the main element in the internal marketing: service training programs, performance incentives, and vision for service excellence key elements of internal marketing, Rafiq and Ahmed (2000) recognize the major elements of internal marketing: employee motivation and satisfaction, customer orientation and customer satisfaction, interfunctional co-ordination and integration, marketing-like approach to the above, and implementation of specific corporate or functional strategies. All scholars mention the main element in the internal marketing with different perspectives to the sector that organization work within. In this study, the following internal marketing elements have been applied to connect it to the marketing performance management:

* Motivation: the movement of employees to act ina preferred manner, it is a professional uses of high-level selfregulated learning strategies, such as tacking attention, connection, planning, and monitoring (Mark \&Robert, 1998; Turner,1995). Broussard and Garrison (2004) explained the motivation as"the attribute that moves us to do or not to do something". The core of the motivation is the ability to lead other and steering them by themselves according the management perspectives and approaches.

* Empowerment: The participation is a process by which control is joint among individuals who are otherwise hierarchically sequenced (Locke and Schweiger, 1979; Wagner, 1994). The description of the empowerment includes a venue to enable employees make their decisions (Bowen \& Lawler, 1992).

* Communication: Communication is a vital precondition for a well functioning organizational culture, without employees being able or ready to communicate with each other, there will be no inter-departmental or interfunctional co-ordination. Communication a process within an organization whereby employee sex change messages (Dwyer,2012; Tourani et al. 2012)

* Training and development: Training increase or develop the managerial skills it is a systematic development of the knowledge, skills and attitudes required by employees to perform adequately on a given task or job (Abiodun, 1999;Rosti \& Shipper,1998;Saleem et al. 2011,Shipper, 1998).

In the case of Jordan, Awwad \& Agti (2011) explained that the Jordanian banks should build internal marketing as a strategy into their core operations and systems to meet employees' demands and the bank goals, and this conversion shall make employees show their sincere organizational commitment so that they can express the attitude of organizational citizenship behaviors that are beneficial for the banks' operations and survival.

\section{Marketing Performance Management:- Marketing Performance:-}

The marketing performance cannot be isolated from the overall organizational performance for the organization. Thus, marketing performance that link marketing activities to organizational performance are vital to integrating marketing management with the organization's decision-making and operating processes (Frosén et al., 2008), moreover the performance of the marketing is connected directly to the internal marketing in the organization. Marius \& Nicoleta (2013) explained that the marketing performance management has been one of the important approaches in current marketing practice and research, Kotler (2009) have been mentioned the concept of the marketing metrics to measure the marketing performance, the marketing performance management systems concept have been coined by Lamberti and Noci, (2010), all concepts that have been mentioned try to explain the need for the performance measurement, this measuring for the marketing performance is a crucial management issue that must be managed. Thus marketing performance emerged as critical issue in the marketing management.

\section{Marketing Performance Management:-}

The use of the performance indicators which are must be identified, monitored, and communicated as a backbone of the performance management in the marketing (Brudan,2010), some scholars mentioned the marketing performance management as "marketing performance measurement" and adding to the main process: marketing planning, 
execution, and use of marketing results for performance improvement (Meekings et al., 2009). The marketing performance management is an umbrella term, it is means different things for different people, but many scholar have many definitions for it, CMG Partners and Chadwick Martin Bailey (2010) defined marketing performance management as "the discipline and practice of measuring, learning from and improving marketing strategies and tactics over time", this definition concentrating on the continuity of the marketing performance practices, another scholar Patterson (2010) mentioned the marketing performance management as " the practice of managing efficiency and value in marketing by aligning people, processes and systems towards a common set of goals ", this definition come with the purpose of this study which focused on the human element in the organization which is the focal point for the internal marketing. The marketing considered to be in the organization; the separation of the marketing and sales, the marketing performance management can be defined according what it is measured particularly in organizations where there is no specific marketing department. Ambler (2003) mentioned three approaches for marketing:

* Pan-Company Marketing: Marketing as intrinsic orientation of the whole company towards obtaining customer preference and, ultimately, high returns for the shareholders;

* Functional Marketing: Marketing as functional area or department, which may or may not assume profits, products, pricing policies and so on;

* Budget Marketing: Marketing as expenses, most often advertising and promotional spending.

In this study, the marketing performance management is an organization wide direction, the marketing is a process, which must be managed and evaluated in the context of the organization to harmonizing of the marketing mix. The most important elements in marketing performance measurement is the tools used in marketing performance management process, the most popular tools are:

* Marketing Dashboards: which comes from the business intelligence (BI) area, being a form of BI solution that enables the management of a volume of data and the generation of performance reports based on this data.

* Marketing Performance Indicators : which means how the managers evaluate performance and use the information generated by the marketing performance management system

* Marketing Performance Management Systems: which is set of processes and tools that deal with evaluating the performance influenced or driven by marketing (Kotler \& Keller,2011).

The performance cannot mentioned in any study or in any knowledge disciplines without discussing the indicators, marketing performance management have its indicators or performance measures which is called Key Performance Indicators (KPIs). This metrics are tools that quantify a trend, dynamic or characteristic the marketing performance (Reibstein et al.,2006). Parmenter (2009) recognized four kinds of marketing performance measures:

* Key results indicators (KRI), which reflect performance related to a critical success factor.

- Result indicators (RI), which reflect what was done, what was achieved.

* Performance indicators (PI), which reflect what needs to be done.

- Key performance indicators (KPI), which indicate what needs to be done in order to increase performance dramatically.

Kotler\& Keller (2011) defined the marketing metrics as "a set of performance measures that help organization quantify, compare and interpret their marketing performance" moreover Kotler\& Keller (2011) explained that the good marketing metrics have to:

* Be as quantifiable financially as possible;

* Be future oriented (leading), rather than to reflect past performance (lagging);

* Allow a granular analysis of marketing performance (down to the level of individual client);

* Offer objective data, to enable accountability and benchmarking.

All scholars have discussing the performance measure without mentioning the perfect performance measure, the perfect performance measure does not exist. Thus, the organization must have multiple perspectives for marketing performance indicators and to see connected to the multiple dimensions in the organization. Balanced scorecard is a wide and popular tool for measuring performance and it used in the sphere of marketing, based on the performance objective formulation the implicitly of the marketing department in the organization, the on the four perspectives: financial, customer, internal processes and learning and growth are the key element that the balanced scorecard uses to measure the performance. 


\section{Research Framework:-}

The research framework depend on the sector that applied within, banking sector acting an important role in an economy to improve stability and increase economic growth, this central role in the money creation process and in the payment system affects the financing of investment and growth in any country. Thus, a special interest in maintaining banking system stability is a critical development in Jordan (Hartmann et al., 2005). The flowing table include the 15 banks that listed on the Amman Stock Exchange (ASE) in 2013.

Table 1: Banks that Listed on the Amman Stock Exchange (ASE,2013).

\begin{tabular}{|c|l|}
\hline no & Arab bank \\
\hline 1. & Jordan islamic bank \\
\hline 2. & Jordan kuwait bank \\
\hline 3. & Jordan commercial bank \\
\hline 4. & The housing bank for trade and finance \\
\hline 5. & Arab jordan investment bank \\
\hline 6. & Jordan dubai islamic bank \\
\hline 7. & Bank al-etihad \\
\hline 8. & Arab banking corporation /(jordan) \\
\hline 9. & Invest bank \\
\hline 10. & Capital bank of jordan \\
\hline 11. & Societe generale de banque - jordanie \\
\hline 12. & Cairo amman bank \\
\hline 13. & Bank of jordan \\
\hline 14. & Jordan ahli bank \\
\hline
\end{tabular}

\section{Problem of the Study:-}

The purpose of this Study is the human element in the organization which is the focal point for the internal marketing, the marketing performance management is the measuring of the marketing performance in the organization that try to developed its competitive posture, the banking industry have some pattern that comes from the direct influence of the of the employee that worked with the customers, the employees play a significant role in the marketing and delivering the banks products, which exaggerated responsibility of the marketing roll of the employees.

\section{Objectives of the study:-}

The main objective of the research is achieving the following objectives:

* Define the concept of the internal marketing as a whole and to identify variable-scale widespread of this concept in the Jordanian banking sector, and explaining the relationship with marketing performance management.

* Finding the effect of the internal marketing on the marketing performance management.

- Provide scientific study of scientific specialists and decision-makers interested in the Jordanian banking industry.

\section{Importance of the Study:-}

This study is the first in this topic, according to researcher information at the local (Jordanian) and the Arab world, where the studies always refers focusing only on the internal marketing and the marketing performance management. Thus, the importance this study came from a scientific and academically analysis the correlation between the variables of the study, and the effect of the independent variable and the dependent variable. The importance of the study practically is applying the results in the Jordanian banking industry for the first time, the study aspiring to reach some useful results for those involved in decision-making and strategies formulation in marketing. 


\section{Research Model:-}

Figure 1 depict the research model, it is explaining the dependant variable (Internal marketing) and the independent variable (Marketing Performance Management).

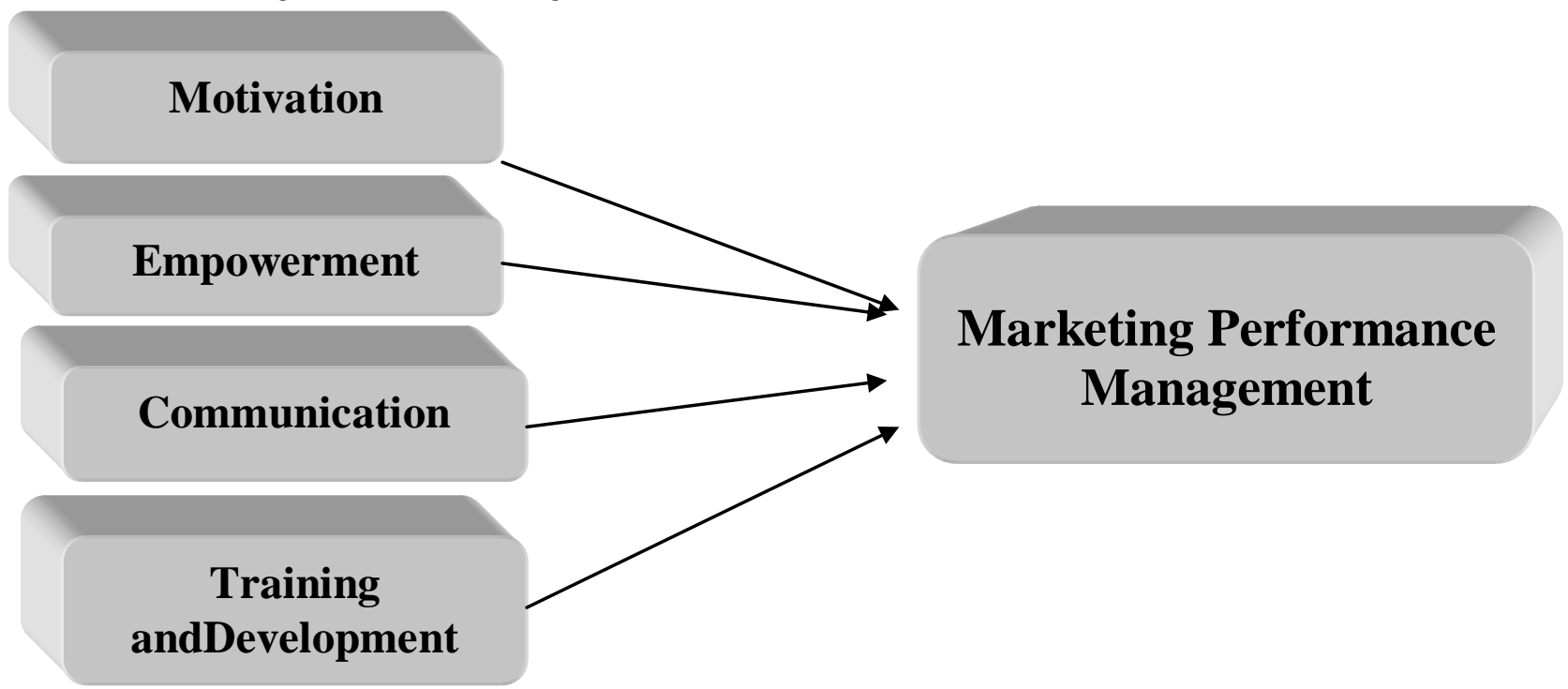

Figure 1: The Research Model.

The research model explained the relationship between the research variables and the interdependently be the variables, which is electively helping the understanding of the research hypothesis.

\section{Research Hypotheses:-}

Based on the problem of the study and its objectives and consistent with objective to study border the researcher aimed to test the following hypotheses:

* (H1): There is a statistically significant effect of internal marketing (motivation) on marketing performance management at $(0.05 \leq \mathrm{p})$ in the Jordanian banks.

* (H2): There is a statistically significant effect of internal marketing (empowerment) on marketing performance management at $(0.05 \leq \mathrm{p})$ in the Jordanian banks.

* (H3): There is a statistically significant effect of internal marketing (communication) on marketing performance management at $(0.05 \leq \mathrm{p})$ in the Jordanian banks.

* (H4): There is a statistically significant effect of internal marketing (Training and development) on marketing performance management at $(0.05 \leq \mathrm{p})$ in the Jordanian banks.

\section{The Study Methodology and Tool:-}

The researcher depend on the descriptive analytical approach, as one of the research methodology adopted in the behavioral and social sciences, that examine the sources and references relevant variables of the study, a self administrated questionnaire was developed to explore the relationship between the variables.

The reliability of the questionnaire items have been tested using the Gronbach's Alpha test. Table 2 shows the values of the questionnaire dimensions.

Table 2: Cronbach's alpha coefficients to test the stability study tool.

\begin{tabular}{|l|c|}
\hline Dimensions & Cronbach's Alpha Coefficient \\
\hline Motivation & 0.82 \\
\hline Empowerment & 0.88 \\
\hline Communication & 0.86 \\
\hline Training And Development & 0.81 \\
\hline Marketing Performance Management & 0.83 \\
\hline Average & 0.84 \\
\hline
\end{tabular}

The table 2 shows that the total average Cronbach's alpha coefficient $(0.84)$ is accepted. 


\section{Population and Sample of the Study:-}

The community total to study consisted from the banks that listed on the Amman Stock Exchange (ASE,2013), table 3 shows number questionnaires that have been distributed on the main banks directorate.

Table 3: The number questionnaires that have been distributed banks.

\begin{tabular}{|l|c|}
\hline Name of the bank & Number of Questionnaires \\
\hline Arab bank & 14 \\
\hline Jordan islamic bank & 11 \\
\hline Jordan kuwait bank & 10 \\
\hline Jordan commercial bank & 13 \\
\hline The housing bank for trade and finance & 14 \\
\hline Arab jordan investment bank & 12 \\
\hline Jordan dubai islamic bank & 16 \\
\hline Bank al-etihad & 14 \\
\hline Arab banking corporation /(jordan) & 13 \\
\hline Invest bank & 11 \\
\hline Capital bank of jordan & 15 \\
\hline Societe generale de banque - jordanie & 9 \\
\hline Cairo amman bank & 13 \\
\hline Bank of jordan & 15 \\
\hline Jordan ahli bank & 13 \\
\hline Total & $\mathbf{1 9 3}$ \\
\hline
\end{tabular}

\section{Data Analysis and Hypothesis Test:-}

The Dimension and its mean, slandered deviation, percentage, the degree of approval, and the rank have been explained in table 4.

Table 4: Averages and standard deviations for expressive areas of study for the independent and dependent variable.

\begin{tabular}{|l|l|l|l|l|l|}
\hline Dimension & Mean & $\begin{array}{l}\text { Standard } \\
\text { Deviation }\end{array}$ & Percentage & $\begin{array}{l}\text { Degree of } \\
\text { Approval }\end{array}$ & Rank \\
\hline Motivation & 3.7277 & 0.64687 & 74.6 & High & 4 \\
\hline Empowerment & 3.8732 & 0.53389 & 77.5 & High & 3 \\
\hline Communication & 3.7014 & 0.57656 & 74.0 & High & 5 \\
\hline Training And Development & 3.2507 & 0.59013 & 65.0 & Medium & 7 \\
\hline $\begin{array}{l}\text { Marketing Performance } \\
\text { Management }\end{array}$ & 4.3296 & 0.46118 & 86.6 & High & 1 \\
\hline
\end{tabular}

As shown in table (4) that the values of arithmetical averages ranged to the degree approval study sample on the areas of variable study independent "Empowerment" from (3. 8732) percentage (77.5\%) at its highest for the field, " Training And Development " have the lowest degree of approval. The dependent variable in the field of " Marketing Performance Management " (4.3296) percentage (86.6\%) which have a the highest degree of approval in the overall study variables .

\section{Hypotheses Test:-}

The presence of a statistically significant impact of internal marketing on the marketing performance management at the level of significant $(0.05 \leq \mathrm{p})$. Table (5) shows the simple Regression analysis results for the hypothesis.

Table 5: Simple Regression Analysis Results for the Hypothesis.

\begin{tabular}{|l|c|c|c|}
\hline Dimension & B & T & Sig. \\
\hline Internal Marketing & 0.108 & 1.49 & 0.001 \\
\hline Marketing Performance Management & 0.082 & & \\
\hline
\end{tabular}

The table (5) shows that the force majeure and coercion is practiced a significant influence on management time and shows it by the value of $\mathrm{F}(2.34)$, a value that is significant at the level of 0.05 . Which leads us to accept the 
hypothesis, which states: There is a statistical significant impact of the internal marketing on the marketing performance management at $(0.05 \leq \mathrm{p})$ in the Jordanian banks.

(H1): H1): There is a statistically significant effect of internal marketing (motivation) on marketing performance management at $(0.05 \leq \mathrm{p})$ in the Jordanian banks.

To test the first hypothesis the researcher using simple regression analysis test, table (6):

Table 6: Result of regression analysis to test first sub- hypothesis of the main hypothesis.

\begin{tabular}{|l|c|c|c|}
\hline & B & T & Sig. \\
\hline Motivation & 0.01 & 0.01 & 0.01 \\
\hline R2 & 0.001 & & \\
\hline F & 0.024 & & \\
\hline
\end{tabular}

The table (6) that the motivation and exercise a significant impact on marketing performance management and shows through $\mathrm{F}$ value of amounting (0.024), a value that is significant at the level of 0.05 , which also shows the significance model. From the previously we are able to accept the hypothesis, which states: There is a statistically significant effect of internal marketing (motivation) on marketing performance management at $(0.05 \leq \mathrm{p})$ in the Jordanian banks.

(H2): There is a statistically significant effect of internal marketing(empowerment) on marketing performance management at $(0.05 \leq \mathrm{p})$ in the Jordanian banks.

To test the second hypothesis the researcher using simple regression analysis test, table (7):

Table 7: Result of regression analysis to test the hypothesis secondsub-hypothesis of the main hypothesis.

\begin{tabular}{|l|c|c|c|}
\hline & B & T & Sig. \\
\hline Empowerment & 0.747 & 8.478 & $0.000^{*}$ \\
\hline R2 & 0.24 & & \\
\hline F & 71.879 & & \\
\hline
\end{tabular}

The table (7) to that empowerment exercise significant influence on the marketing performance management through $F$ value of amounting (71.879), a significant value at the 0.05 level, which also shows the significance model. From the previously we are able to accept the hypothesis which states: There is a statistically significant effect of internal marketing(empowerment) on marketing performance management at $(0.05 \leq p)$ in the Jordanian banks.

(H3): There is a statistically significant effect of internal marketing(communication) on marketing performance management at $(0.05 \leq \mathrm{p})$ in the Jordanian banks.

To test the third hypothesis the researcher using simple regression analysis test, table (8) :

Table 8: Result of regression analysis to test the hypothesis thirdsub- hypothesis of the main hypothesis.

\begin{tabular}{|l|c|c|c|}
\hline & B & T & Sig. \\
\hline Communication & 0.663 & 12.839 & $0.000^{*}$ \\
\hline F2 & 0.421 & & \\
\hline
\end{tabular}

The table (8) to that hypocrisy communication exerts significant effect on marketing performance management is shown by the value of $F$ (164.83), a significance value at the 0.05 level, which also shows the significant model. From the previously we are able to accept the hypothesis which states: There is a statistically significant effect of internal marketing (communication) on marketing performance management at $(0.05 \leq p)$ in the Jordanian banks.

(H4): There is a statistically significant effect of internal marketing(Training and development) on marketing performance management at $(0.05 \leq \mathrm{p})$ in the Jordanian banks. To test fourth hypothesis, the researcher using simple regression analysis test, table (9):

Table 9: Result of regression analysis to test the hypothesis fourthsub-hypothesis of the main hypothesis.

\begin{tabular}{|l|l|l|l|}
\hline & B & T & Sig. \\
\hline Administrative Hypocrisy & 1.091 & 8.5554 & $0.000^{*}$ \\
\hline R2 & 0.244 & & \\
\hline F & 73.167 & & \\
\hline
\end{tabular}


The table (9) that the Training and developmentpracticed administrative significant effect on marketing performance management and it shows through the value of $F$ (73.167), a significance value at the 0.05 level, which also shows the significant model.From previously we are able to accept the hypothesis, which statesThere is a statistically significant internal marketing effect of (Training and development) on marketing performance management at ( 0.05 $\leq \mathrm{p}$ ) in the Jordanian banks.

\section{Results and Recommendations:-}

Results:-

Based on the analysis of data the study found the following results:

* There is a statistically significant effect of internal marketing (motivation) on marketing performance management at $(0.05 \leq \mathrm{p})$ in the Jordanian banks.

* There is a statistically significant effect of internal marketing (empowerment) on marketing performance management at $(0.05 \leq \mathrm{p})$ in the Jordanian banks.

* There is a statistically significant effect of internal marketing (communication) on marketing performance management at $(0.05 \leq \mathrm{p})$ in the Jordanian banks.

* There is a statistically significant effect of internal marketing (Training and development) on marketing performance management at $(0.05 \leq \mathrm{p})$ in the Jordanian banks.

* The study revealed the existence of a strong correlation between internal marketing and marketing performance management, because of the existence of attention for internal marketing for employees at the Jordanian banks.

* The study sample agreed that the internal marketing organizational widespread practice, not an individual and has a significant impact on the efficiency and effectiveness of the banks marketing performance management.

\section{Recommendations:-}

* Spreading the culture of internal marketing and support of senior management at the Jordanian banks.

* to identify an ambitious plans that represent the vision and fulfill its internal marketing mission as a participatory between everyone when developed and implemented, and not to keep these plans locked drawers offices.

* The marketing management must work on the review as an ongoing internal marketing process to lever the marketing performance management of the Jordanian banks.

* Study concludes that the marketing performance management related to proper planning and follow-up of the internal marketing within the Jordanian banks, especially related to the labor market, to ensure supplying various sectors elements of qualified human resources.

\section{References:-}

1. Abzari, M., \&Ghujali, T. (2011). Examining The Impact Of Internal Marketing On Organizational Citizenship Behaviour. International Journal Of Marketing Studies, 3(4), 1-11. Http://Dx.Doi.Org/10.5539/Ijms.V3n4p95

2. Al-Hawary,I,S., Kamal A. M. Al-Qudah, Petra Mash'alAbutayeh, SherrihanMash'alAbutayeh , DyalaYahya Al-Zyadat (2013)"The Impact Of Internal Marketing On Employee's Job Satisfaction Of Commercial Banks In Jordan", Interdisciplinary Journal Of Contemporary Research In Business,Institute Of Interdisciplinary Business Research ,January 2013 Vol 4, No 9, Available Online At: Http://JournalArchieves27.Webs.Com/811-826.Pdf.

3. Ambler, T. (2003), Marketing And The Bottom Line: The Marketing Metrics To Pump Up Cash Flow, Pearson Education, London

4. Amman Stock Exchange,(2013) "Annual Report", Amman, Jordan Available At: Http://Www.Ase.Com.Jo/Sites/Default/Files/Annual_Report_E_2013.Pdf

5. Bdour, J.I. And Al-Khoury, A.F. (2008). "Predicting Change In Bank Efficiency In Jordan: A Data Envelopment Analysis", Journal Of Accounting And Organizational Changes, Vol. 4, Pp. 162-181.

6. Berry, L. (1981). “The Employee As Customer”, Journal Of Retail Banking, Vol. 3.

7. Bowen, D.E., \& Lawler, E.E. (1992). "The Empowerment Of Service Workers: What, Why, How And When", Sloan Management Review, Vol. 33 No. 3, Pp. 31-39.

8. Broussard, S. C., \& Garrison, M. E. B. (2004). The Relationship Between Classroom Motivation And Academic Achievement In Elementary School-Aged Children. Family And Consumer Sciences Research Journal, Vol.33, No.2, Pp.106-120.

9. Brudan, A. (2010), "Rediscovering Performance Management: Systems, Learning And Integration”, Measuring Business Excellence, Vol. 14, No. 1, Pp. 109-123 
10. CMG Partners AndChadvick Martin Bailey (2010), "The Marketing Performance Advantage. Improving Effectiveness And Accountability", Available At:Http://Www.Cmgpartners.Com/Userfiles/CMGPCMB\%20Marketing\%20Performance\%20Advantage\%20\% 20BMA\%20presentation\%20\%283-16-09\%29.Pdf,(Accessed March 22.( 2015)

11. Dwyer, Judith. (2012)" The Business Communication Handbook ", 9th Ed.,Frenchs Forest, N.S.W. Pearson Australia, ISSN:47430859

12. Ezekiel,P,. Pearse,(2014)," Internal Marketing As A Strategic Tool For Survival In Nigeriabanking Industry ",OSR Journal Of Business And Management (IOSR-JBM),E-ISSN: 2278-487X, P-ISSN: 2319-7668. Volume 16, Issue 6. Ver. II (Jun. 2014), PP 141-149

13. Frosén, J., Jaakkola, M., Vassinen, P. P. \&Aspara, J. (2008). "Use And Perceived Importance Of Marketing Metrics In Different Business Settings". Proceedings Of The 2008 Conference Of ANZMAC,Sydney, 1-3 December 2008.

14. Hartmann, P., Straetmans, S. And De Vries, C. (2005). "Banking System Stability: A Cross-Atlantic Perspective". European Central Bank Working Paper Series No. 527 (September), European Central Bank, Frankfurt, Germany.

15. Hartmann, P., Straetmans, S. and De Vries, C. (2005). "Banking System Stability: A cross Atlantic Perspective".European Central Bank Working paper series No. 527 (September), European Central Bank, Frankfurt, Germany.

16. Hogg, G., Carter, S. \& Dunne, A. (1998). "Investing In People: Internal Marketing And Corporate Culture",Journal Of Marketing Management, Vol. 14, Pp. 879-895.

17. JaveriaShabbir,Rashid A. Salaria.(2014),"Impact Of Internal Marketing On Employee Job Satisfaction: An Investigation Of Higher Education Institutes Of Pakistan",Journal Of Marketing Management,June 2014, Vol. 2, No. 2, Pp. 239-253 ISSN: 2333-6080 (Print), 2333-6099 (Online)

18. Kotler, P., Keller, K.L. (2011), Marketing Management,, 14th Edition ,Pearson Education Limited, London.

19. Lamberti, L. And Noci, G. (2010), „Marketing Strategy And Marketing Performance Measurement System: Exploring The Relationship", European Management Journal, Vol. 28, No. 2, Pp.139-152

20. Locke, E. A. \&Schweiger, D. M. (1979). "Participation In Decision-Making: One More Look", Research In Organizational Behavior, Vol. 1 No. 10, Pp. 265-339.

21. Marius D. POP., Nicoleta-Dorina RACOLŢA-PAINA,(2013)"THE "WHAT” AND "HOW” OF MARKETING PERFORMANCE MANAGEMENT", Management And Marketing Challenges For The Knowledge Society(2013) Vol. 8, No. 1, Pp. 129-146

22. Mark A. Tietjen, Robert M. Myers, (1998) "Motivation And Job Satisfaction", Management Decision, Vol. 36,No. 4, Pp. 226 - 231.

23. Meekings, A., Povey, S. And Neely, A. (2009), „Performance Plumbing: Installing Performance Management Systems To Deliver Lasting Value”, Measuring Business Excellence, Vol. 13,No. 3, Pp. 13-19

24. Mills, H.,(2010)," An Investigation Of The Marketing Performance Measurement Practices Of South African Organisations", University Of Stellenbosc, South Africa.

25. Mohammad Suleiman Awwad, Djouhara Ali Mohammad Agti, (2011) "The Impact Of Internal Marketing On Commercial Banks' Market Orientation", International Journal Of Bank Marketing, Vol. 29 Iss: 4, Pp.308 - 332

26. Parmenter, D. (2009), Key Performance Indicators: Developing, Implementing And Using Winning Kpis, John Wiley And Sons, Hoboken

27. Rafiq, M. And Ahmed, P.K. (2000). “Advances In The Internal Marketing Concept: Definition, Synthesis And Extension”, Journal Of Services Marketing, Vol. 14 No. 6, Pp. 449-62.

28. RajiSrinivasan And SundarBharadwaj,(2004)," Event Studies In Marketing Strategy Research " Marketing Science Institute Published 1000 Massachusetts Ave.Cambridge,,USA

29. Reibstein, D., Farris, P., Bendle, N. And Pfeifer, P. (2006), Marketing Metrics: 50+ Metrics Every Executive Should Master, Wharton School Publishing, Upper Saddle River

30. Rosti, R. T., \& Shipper, F. (1998). A Study Of The Impact Of Training In A Management Development Program Based On 360-Degree Feedback. Journal Of Managerial Psychology, Vol.13,Pp. 77-89.

31. Saleem, Qasim, Shahid, Mehwish and Naseem, Akram (2011) "Degree of Influence of Training and Development on Employees Behavior", International Journal of Computing and Business Research.

32. Shiu, M \& Yu, T. W(2010). Internal Marketing, Organizational Culture, Job Satisfaction And Organizational Performance In Non- Life Insurance. The Service Industries Journal, Vol. 30(6), Pp. 793-806.

33. Srivastava, Rajendra K., Tasadduq A. Shervani, And Liam Fahey (1998), "Market-Based Assets And Shareholder Value: A Framework For Analysis." Journal Of Marketing 62 (January),2-18. 
34. Tourani, Azadeh\&Rast, Sadegh (2012). "Effect Of Employees' Communication And Participation On Employees' Job Satisfaction: An Empirical Study On Airline Companies In Iran", 2nd International Conference On Economics, Trade And Development, Vol. 36.

35. Tsai, Y. \& Tang, T. (2008). "How To Improve Service Quality: Internal Marketing As A Determining Factor”, Total Quality Management And Business Excellence Review, Vol. 19, Pp. 1117-1126.

36. Turner, J. C. (1995). The Influence Of Classroom Contexts On Young Children's Motivation For Literacy. Reading Research Quarterly, Vol. 30, No.3, Pp.410-441.

37. Wagner, J. A. (1994). "Participation's Effects On Performance And Satisfaction: A Reconsideration Of Evidence", Academy Of Management Beview, Vol. 19, Pp. 312-330.

38. Woodruffe, H., 1995. Services Marketing, Pitman, London. 